\title{
Religious Pluralism and Religious Imagination: Can a Pluralistic Theology Sustain Christian Faith?
}

\author{
Paul F. Knitter
}

\begin{abstract}
"Does a pluralist theology of religions spell the death of the religious imagination?" 1 - That, I take it, is the question we are all wrestling with in this conference. Or, to phrase the issue in my own language: Is the essential role played by the imagination in the experience of faith jeopardized by a theology that sees Christianity as one among many other universal and valid religions?

To lay out fully the content and concerns of the question would possibly require another paper in itself. I don't want to get bogged down, as theologians often do, in first honing definitions and sorting out distinctions. But some clarity on how we (or, at least I) understand the terms of our conversation is necessary.
\end{abstract}

\section{The Terms of the Conversation}

So first of all, the much discussed and controversial - and I must add, often misunderstood - pluralist theology of religions. Since I've been dubbed a proponent of said theology, the first thing I should say is that I don't like the name. It's misleading. It suggests that this theology affirms pluralism, or manyness, as its highest good and guiding criterion. "The more the merrier! Let diversity abound! And never say that one piece of this diversity is better than another." - Such an understanding of the pluralist theology of religions doesn't reflect what I'm about as a pluralist theologian. For me, and for most of the pluralists I walk with, our "highest good" or goal is not diversity but dialogue, not 2000

1. In Terrence Merrigan's official letter of invitation to participants, 4 September 
the simple fact of having lots of religions but enabling those religions to talk to, and learn from, and work with each other. So our intent is not to affirm the equality of all religions but rather, to enable all religions, whatever their ingredients or however they might be ranked, to enter into a genuine conversation.

That's why in recent publications, I've tried to change the terms of the conversation. Instead of a pluralist theology of religions, I suggest that what people like John Hick, Raimon Panikkar, Roger Haight, Stanley Samartha, Rosemary Radford Ruether, Michael Amaladoss are about can better be captured by the term, a correlational theology of religions, or even more accurately, a theology of mutuality. ${ }^{2}$ This theology seeks to foster - and that means, remove the obstacles to - a more authentic relationship of mutuality among the religious families of the world. (In this paper, however, I'll stick to the nomenclature given us and refer to myself, reluctantly, as a "pluralist.")

The other pole of our conversation - the religious imagination - is less slippery and controversial. As Terrence Merrigan has clarified in his initial communications with us, we're working with Cardinal Newman's foundational understanding of the integral role the imagination plays in the genesis of faith. The imagination has been called, in traditional terminology, a "faculty" - something real, an ability that religious believers find and feel within themselves, an ability that both identifies and then empowers the very act and content of faith. Merrigan, in a personal letter to me, summarizes neatly Newman's depiction of the religious imagination: "The imagination is best regarded as both an evocative and a constructive 'faculty' - it is able to 'evoke' emotions and even action, in view of the object it 'constructs' ... worship and devotion is essential to 'lived' religion, and that worship and devotion require an object, a goal which is regarded by the believer to be real and, as it were, 'accessible.' This object is essentially the 'creation' of the religious imagination ... The religious object is mediated through the imagination." 3

2. For representative statements of Hick, Panikkar, Samartha, and Ruether see John Hick \& Paul F. Knitter (eds.), The Myth of Christian Uniqueness: Toward a Pluralistic Theology of Religions (Maryknoll, NY: Orbis Books, 1987). Roger Haight, "Jesus and the World Religions," Jesus Symbol of God (Maryknoll, NY: Orbis Books, 2000) 305-423. Michael Amaladoss, "The Mystery of Christ and Other Religions: An Indian Perspective," Vidyajyoti 63 (1999) 327-338; id., "An Indian Christology: The Dialogue Continued," Vidyajyoti 63 (1999) 600-602. For preferring a 'correlational' rather than a 'pluralistic' theology of religions, see Paul F. Knitter, One Earth Many Religions: Multifaith Dialogue and Global Responsibility (Maryknoll, NY: Orbis Books, 1995) 23-25.

3. In an email dated 12.31.00. 
To translate and lay out Newman's understanding of the role of the religious imagination, I find myself reverting, happily, back to my student days at the Gregorian University and my course with Fr. Juan Alfaro, S.J. on De Fide Divina. Scholastic theology makes the distinction between fides quae and fides qua. "Fides quae" is the content of faith, what we believe - the stories, the doctrines, the creeds. "Fides qua" is how we believe - that is, how the content, or the stories and creeds, actually get inside us and stir our hearts and hands, how they move us to trust, to commit ourselves, and become disciples.

Perhaps we can better grasp this distinction and the dynamic that explains the genesis of faith with terms that seem available only in the English language. Many a theologian has creatively played with the difference between faith and belief. ${ }^{4}$ Faith is the very act of believing or trusting. It takes place within the deepest recesses of our heart and feelings; it is intensely personal and swims in the waters of ineffability - a gifted feeling we can't ever fully put into words. Beliefs are both the words we do use to give some kind of voice to faith, and at the same time they are the words that triggered the feeling in the first place. Often, the difference between faith and belief is understood as a matter of chronology: first faith and then belief. Really, their inter-relatedness is more a matter of simultaneity. I would even say "non-duality": they're not "two," but neither are they "one." Beliefs give rise to faith. Yet beliefs, without faith, are empty husk, just words. Faith, once born, needs beliefs to incarnate itself in one's life and in the world, and yet it contains a surplus of meaning that can never be captured in words. But as intertwined and necessary as they are to each other, they are definitely different. To forget the difference is to slip into the idolatry of beliefs or the otherworldliness of faith. ${ }^{5}$

Now, we might say that the religious imagination, as understood by Newman, is the link between faith and beliefs (or, in my traditional terminology, between fides quae and fides qua). The imagination is what presents the story or the doctrine as interesting and then, ignites it with the power to take hold of us and elicit our commitment. It "creates" and "evokes."

4. Bernard Lonergan, Method in Theology (New York: Seabury, 1972) 108-111, 115-119. Wilfred Cantwell Smith, The Meaning and End of Religion (New York: New American Library, 1964) chapter 6. Raimon Panikkar, "Faith and Belief: A Multireligious Experience," Anglican Theological Review 53 (1971) 228-229.

5. I fear that this is precisely what happens in many so-called postmodern perspectives that insist not only that language determines but that it also confines or captures experience. See George Lindbeck, The Nature of Doctrine: Religion and Theology in a Postliberal Age (Philadelphia, PA: Westminster Press, 1984). 


\section{How the Religious Imagination Works}

But just how does the imagination actually do this? What gives it the ability and the power to transform beliefs into faith, words into feelings, and then feelings into words? Newman's reflections on the role of the imagination were based, to be sure, on careful speculation; but more fundamentally, those reflections were rooted in his own religious experience, and, he expected, could be confirmed by others who shared such experiences. Which means: when we ask just how or why the imagination works the way it does, we step into the domain of what Christians call the Holy Spirit. Speaking perhaps too crudely, we can say that the religious imagination is the instrument or the vehicle by which the Spirit touches or invades us. Once our minds have understood the content of a particular doctrine or story, the Spirit uses the imagination to connect that meaning to our own lives, to our own needs or searchings.

The particular meaning in a belief, comprehensible in itself, becomes under the power of the Spirit meaning for me, meaning that illumines the path of my life. The content of a particular image - say, for example, the cross, the resurrection, the transfiguration - becomes a light by which we suddenly understand the particular pains or confusions or hopes of our own journey. Speaking more generally, we can say that through the Spirit working in and through the story of Jesus, this story becomes our own story. What Jesus said and did, how he is portrayed in the Gospels and liturgy, springs to life for us and becomes the "Master-Story" by which we can now understand and plot and risk our own still unfinished story. All this happens through the way that our imagination, filled with the Spirit, hears and feels the story of Jesus - or, the way the Gospel story, illumined by the Spirit, touches and activates our imagination. What was just a story becomes a revelation and invitation. The story calls forth faith and becomes belief.

Let me add one more piece - and for me a pivotal piece for this paper - to these explorations of just how the religious imagination works. To say that a particular belief becomes enflamed by the imagination under the workings of the Spirit and so becomes an act of faith - this is to say that this belief or ritual or ingredient of the tradition is functioning for the imagination as a symbol. When a story becomes my story, when an image takes hold of my soul, then that story has become, in the technical language of theology and anthropology, a myth; then that image is working as a symbol. ${ }^{6}$

6. I understand a religious myth to be a revelatory narrative that makes use of symbols - whether the narrative is historical or not, whether the symbols are taken literally or not. 
As is commonly understood in Christian, especially Catholic, theology, a symbol is that which mediates Something greater or more than itself, but Something in which it (the symbol) participates and is rooted. There is, as theologians put it, a mediated immediacy to be experienced in symbols. The power and presence of the Divine is immediately, directly present to us; and yet that presence is embodied in the symbol and would not be so present to us without the symbol. In a dialectical tension that can never be transcended, the symbol both is and is not the Reality it makes real. Because the symbol so enflames and engages the imagination as to reveal the Divine, we know that it, somehow, is part of the Divine. Thus, someone whose imagination has been truly grasped by a symbol would never say of it that it is "only a symbol." At the same time, however, to simply identify the symbol with the Divine so as to lose all difference between the two would be an act of idolatry. ${ }^{7}$

The religious imagination, therefore, works through symbols. Its Spiritfilled capacity to transform fides quae or traditum (what has been passed on) into fides qua or traditio (what is being passed on) can be understood as a process in which the imagination, always inspired by the Spirit, transforms a particular belief into a symbol - or perhaps more accurately, a process in which the imagination reveals that this belief or doctrine or story is a symbol. And because it is a symbol, by being a symbol, it makes the Divine present to us and for us. As the Scholastics put it: symbolizando causant. By symbolizing the Divine, they cause the Divine to be present. The Catholic word for symbols, as is evident, is sacrament. To talk about the role of the imagination in the genesis of faith, then, is to talk about sacraments.

\section{What the Religious Imagination Communicates}

From our considerations of how the religious imagination works, I move closer to the core of our conference topic by asking what are the qualities of the symbols that it makes use of. Here I want to explore what the religious imagination has to "feel" or "know" in a particular belief in order for it to evoke from that belief the power of faith. How must a symbol or sacrament affect us, what does it have to tell us, in order for it to really be a sacrament and effectively stir our imagination? In trying to answer those questions, I must confess (or warn) that I will be drawing not only on my training as a theologian but also, and especially, on my

7. For a concise review of the role of symbols in religious life, especially in Christology, see Roger Haight, Jesus Symbol of God (Maryknoll, NY: Orbis Books, 2000) 196-207. 
experience as a Christian. In what follows in this section, I am trying to enter into the psychology of coming to believe, the personal experience of sensing and feeling my imagination fired by the Spirit and so enabled to identify Jesus as my Way, Truth, and Life. Thus, what follows is deeply personal; but I also trust that it reflects what takes place in the heart, or imagination, of others who chose to become followers of Jesus in the Christian community.

I am asking: what is felt or known about Jesus that is essential in order for the Jesus story to become my story? I'm trying to answer that question primarily on the basis of what my experience tells me before that experience becomes further elaborated in doctrine and theological reflection. I know that such a "before" is not entirely possible, for experience is always embodied and mediated in words. And yet, as I already observed, the distinction between experience and word, between faith and belief, is a real distinction. Through the words, then, I'm trying to get at essential qualities of the experience. Let me offer what I think are three such essential qualities of what Christians must imagine and feel about Jesus in order for him to effectively be for them the Symbol or Sacrament of God.

\section{Universally True}

When the religious imagination works, when it creates and evokes the movement of trust and commitment in a person's heart, it is telling the person that what $s /$ he is feeling and knowing is really so. It is true. This is who God is, or how God acts, or what God does. Though it is beyond empirical proof, the believer knows, because the believer is enabled by the Spirit to trust, that this is so. More precisely, what the imagination tells the Christian about the God revealed in Jesus, and about Jesus the revealer of God, is really so, truly part of the way things work in the universe; it comes from the Source of all Truth.

But more: What is communicated through the imagination and affirmed or trusted by the believer is felt to be true not just for me or for my community. If it were "just for us," it could not really be so. "Really" therefore contains "universally." And I am saying that not out of some rational, epistemological principle about the nature of truth (though such a principle, I think, can be elaborated). I am saying that because of what I feel through the power of the imagination - what the Spirit is telling me about Jesus and his message. What I and my fellow Christians have found and been given in this Jesus is true for all people, of all cultures, for all times. Also, I am making this claim not only or primarily because of the missionary mandate delivered in the New 
Testament. I say that because of what I feel, because of what the religious imagination tells me as it calls forth my act of faith. In knowing the truth that is given in Jesus, I feel called to share that truth with others, for I feel that all people need to know and feel what I have known and felt. The lives of all can be so enlightened and transformed as has my life. I want to tell them about Jesus; I want to share what I have found. Yes, I want to preach and proclaim. As Paul put it, "the love of Christ urges me" to share that love with others.

In this experience of how Jesus makes known to and through our imagination what is truly and universally so about God, we have the seeds out of which grew the subsequent doctrinal proclamation that "Jesus is the Son of God." (When I say "subsequent," that doesn't rule out "immediate.") With Edward Schillebeeckx and more recently Roger Haight, I believe that the doctrine of Jesus as divine is rooted in the experience of Jesus as Sacrament. ${ }^{8}$ As contemporary New Testament scholarship seems to agree, Christians did not come to proclaim that Jesus was the Son of God because he told them so but because they felt him to be so. ${ }^{9}$ Jesus is truly divine because he is so truly - that means powerfully and effectively - the Symbol of God. This makes for what is nowadays called a "representative Christology," which I will be considering and advocating later.

\section{Decisively Empowering}

Furthermore, for the image and story of Jesus as delivered in the proclamation and celebration of the Christian community to inspire my imagination, it must also effectively call me, and enable me, to follow after him. It must bring about change in my life - or, at least the effort to change. Here we are touching on the New Testament notion of metanoia, of turning one's life around, of not only knowing the truth but doing it - or, of knowing it truly by doing it actually. Such conversion, of course, implies decision. And decision, in its very etymological content, means that I "cut off" a previous direction and set out in a new one. Thus, the religious imagination, in the way it works, has a definite decisive quality about it. It sets me moving in a very clear direction, which usually implies turning from a previous direction. But what I feel in what the imagination evokes from me is not only the clarity of a direction but also, and usually more astonishingly, the power or energy to actually

8. Edward Schillebeeckx, Jesus the Sacrament of Encounter with God (New York: Sheed \& Ward, 1963). Haight, Jesus Symbol of God, chapter 15.

9. I refer here to the general consensus that Jesus did not proclaim himself as the Son of God or preach his own divinity. 
move in that direction. I'm not only given a new map, but the energy to use it - an energy I never thought I had. Here I believe I am pointing out something that all Christians can identify in their own experience: the story of Jesus, as presented to them in their religious imagination, is decisive and it is empowering.

A clarifying illustration of what such decisive empowerment means in Christian life today is contained, I believe, in Edward Schillebeeckx's notion of "negative experiences of contrast." Schillebeeckx helps us balance what is often a too individualistic understanding of the Christian notion of conversion and discipleship. With his rather unwieldy terminology, he calls us to identify in our common human experiences those situations in our lives where we find ourselves, spontaneously and unambiguously, saying "no" to the horrible realities in our world of human and environmental suffering due to injustice. Confronting a starving child whose parents cannot feed her because their land was taken over by a wealthy landowner, or standing at the banks of a river polluted and deadened by the toxic waste dumped by a careless or could-care-less factory owner, we find ourselves naturally and immediately voicing in our hearts and lips a "no" - "this should not be." Contained in this "no" and surging out of it is a "yes" that calls us to do something positive in the face of this horrible negativity and suffering. Schillebeeckx calls these natural, spontaneous human sentiments in the face of suffering "pre-religious experiences" which are "accessible to all human beings." They are, as it were, imbedded, first stirrings of the Spirit in the human heart. ${ }^{10}$

Such stirrings becomes fully or explicitly "religious experiences" when they are taken up, confirmed, and empowered by the religious imagination. For Christians, this means when they find that the story of Jesus, as proclaimed and lived in the Christian community, enables them to imagine and then trust that such "no's" to injustice and suffering are indeed grounded in the very being of God. And even more empoweringly, they discover that their positive resolve to do something about such negativities is not just a frantic or futile human gesture but part of the Divine vision and resolve that Jesus called the Reign of God. To say "no" to the world as it is, is necessary. And to say "yes" to the hope of decisively changing this world is possible. Christians know this decisively in the way the Jesus story and symbol affects their imagination.

To experience Jesus and his presence in the Church in this way, as decisively empowering, is to say that "Jesus is Savior." What gives new

10. Edward Schillebeeckx, Church: The Human Story of God (New York: Crossroad, 1990) 5-12. 
direction to our lives, as well as the ability to follow in that direction, brings meaning, purpose, wholeness, vitality to our lives: we are saved. Thus the religious imagination, in portraying Jesus as decisive and powerful, both fills all our creedal language about Jesus as Savior with meaning and at the same calls for such language in order to articulate what it so deeply feels. If the imagination does not so "save" us - that is, if it does not decisively empower us to trust and act that our individual lives and our world can be made whole - it cannot be called, in Newman's sense, the religious imagination.

Overwhelmingly wonderful and mysterious: I offer a further quality of how the religious imagination affects us Christians. In revealing to us in the Jesus story what is universally true and what decisively takes hold of our lives, the Christian religious imagination also elicits the awareness that we stand in the presence of - better, are embraced by - Mystery, for which we sense a profound gratitude. What we have discovered through our imagination's unpacking of the Christ event is as powerful and true as it is utterly beyond our comprehension. It is as mysterious as it is real. In the immanent reality of it, we also sense its ineffable transcendence. And we know this not because we have been told that the infinite God is essentially beyond our finite intellects but because we feel it in our own lives. The imagination makes the revealing, empowering Mystery known to us. And in making it so personally known to us, it brings us to our knees in gratitude and worship. We feel we have been given a gift from a Giver we cannot comprehend, and this feeling brings forth the need to acknowledge the Giver and say "thank you."

This is the stuff of liturgy. Such recognition of Mystery present, and of gratitude for it, is what brings people together to sing and shout and dance. 'How can I keep from singing," as one contemporary hymn puts it. Such singing and dancing is part of the celebration with others that also seems to flow from, or live within, the way the religious imagination affects us. This celebration is both a recognition of the divine Mystery that we have identified in our life (worship in the strict sense), and it is also a needed, public expression of gratitude. To worship and to say thank you is what liturgy is all about.

But we must, again, be careful not to imply a chronological, causal order here - as if we are first moved by the imagination and then we celebrate. The movement is, rather, circular. For it is generally in and through the liturgical life of the community that the religious imagination takes hold of us and shows its power. This is why the role of liturgy cannot be limited to worship and gratitude. It is also an act of remembering. In the repeating of the story in the liturgy of the word, in the embodying of the story in the official sacraments, we keep alive the past in our present. 
In remembering, we share in the story. So in stating that the religious imagination leads to liturgy, we must immediately add that liturgy is the energy field in which the imagination does its work.

These liturgical implications of how the religious imaginations works and what it leads to can be expressed, more particularly, for Christians in the doctrinal claim that the Church is the Mystical Body of Christ, or that the Mystery of God-incarnate-in Jesus continues in the Church. In the way that their imaginations leads them to celebrate and in the way celebrating fires their imagination, Christians know experientially what the catechism teaches: that there is a very real Presence of Jesus in the community and its liturgy. In fact, we can say that it is especially in the liturgy that Easter continues to happen. (I would even venture to say with some Christian scholars that it was in the breaking of bread and communal meals that Easter originally happened. ${ }^{11}$ ) So it is in the workings of the imagination, especially as that imagination is expressed and nurtured in the Eucharistic meals, that the doctrine of the Resurrection becomes not just a belief but a lived experience for Christians. ${ }^{12}$

In these reflections on how the religious imagination works and on what it communicates, we have also indirectly shown how the imagination both leads to and draws its substance and sustenance from the three life-forms of the Christian community (life forms, I would add, that are found in all religions): creed, code, and celebration. In making known to Christians what is really and universally true about Jesus and the Godincarnate in him, the imagination offers the soil out of which all Christian doctrine grows. In decisively empowering Christians and thus calling them to "go and do likewise," the imagination grounds the ethical practice of the Christian community. And in summoning Christians to celebrate, sing their gratitude for, and keep remembering the Mystery that is truly and decisively working in their community, the imagination both calls forth and lives within the Church's liturgy. Or, in the terminology that was given us in Dr. Merrigan's summons to this conference, the religious imagination nourishes and lives within the story, praxis, and spirituality of the Christian communities.

11. Dermot Lane, The Reality of Jesus: An Essay in Christology (New York: Paulist Press, 1975) 61. Haight, Jesus Symbol of God, 136-139.

12. I would immediately add, with Aloysius Pieris, that it is not only in the liturgy that the living Jesus is experienced to be alive and well in the Christian community. Just as much, perhaps even more so, the reality of the Christ-Spirit is powerfully available in the praxis of love-seeking-justice. See Aloysius Pieris, God's Reign for God's Poor: A Return to the Jesus Formula (Kelaniya, Sri Lanka: Tulana Research Centre, 1998) 27-34. 


\section{What the Religious Imagination Does Not Communicate or Require}

But in order to move into the focus of our conference's concerns, I need to say more about how the religious imagination works. I want to explore with you not only what the imagination tells us when it transforms fides quae into fides qua, but also what it does not tell us - and, I would add, what it cannot and what it need not tell us. What I am suggesting to you I find in the way my religious imagination has brought me to recognize Jesus of Nazareth as the Christ of God and in the way it continues to nurture me in my efforts to follow after him as a disciple. Other Christians - especially many of my students and of my fellow parishioners at St. Robert Bellarmine Parish - have confirmed for me that my experience reflects their own.

I suggest two claims which, though they may be givens in traditional Christian doctrine, do not seem to be given by the religious imagination:

\section{Not the Only Story}

Although the religious imagination, in the way it enables me to connect my personal story with the Jesus story, does bring me to fell that the revelation I find in Jesus is really and universally true, it does not tell me that this is the only truth that God may have in store for humanity.

Here we must note a distinction between "universal" and "only." Yes, I am convinced that what I have been given in Christ Jesus should be given to others; the way my life has been touched and transformed could - no, should - happen in the lives of others. But to feel the universal relevance of the Jesus story does not rule out the possibility of there being other, though perhaps very different, universally relevant stories that have also transformed the lives of others. These other religious believers, too, would feel the need and call to share what they have been given. For me the Christian, as I reflect on what my imagination has made known to me about Jesus, I need to share my story, even though there may be other stories which have "saved" the lives of others, yes, even though I myself may be able to learn much from those others stories.

Therefore, although I have no doubts about the truth and importance of the Jesus story, I do not know, in the experience of my own Christian imagination, that it is the only story. I do not know because of two reasons: I cannot and I need not know.

I cannot know that the Jesus story is the only saving story that God has told simply because of the evident fact that my imagination is only my imagination. My experience is limited. To venture the claim that the Christ event is the only saving act of God, I would have to know about 
other religious stories and traditions, I would have to somehow enter into the imaginations of other religious persons. Or, I would have to enter into the very mind and being of God to know that, indeed, God has chosen to act and reveal and save, here and only here. As is evident, finite creature than I am, all such experiences, and all such knowledge resulting from such experiences, is beyond me. Note that the assertions I am making are intended to report on what the religious imagination reveals to me, what I feel in my own Christian experience of coming to believe. Admittedly, Christian belief and doctrine have made such claims about Jesus as the only Savior and the only Son of God. What I am suggesting is that such claims are not inherently confirmed and verified by what my religious imagination or my Christian faith-experience tells me. Their truth value is not immediately mediated in the Christian personal religious experience; it would have to be subsequently mediated. ${ }^{13}$

But if my Christian religious imagination cannot, in the way it works, tell me that Jesus is the only saving act of God, it also doesn't need to. As I try to look into what is going on in the way the Spirit fills and moves my imagination, I realize that what moves me to take the step of faith and make the commitment of discipleship is the assurance I feel that Jesus is truly the Son of God. I really don't need to know whether he is the only Son of God. In a sense, that question is irrelevant. It is not part of what moves me to believe. What does move me is the ability of Jesus to be a Sacrament of salvation for me - a symbol that in its content and Spirit-infused power - excites my imagination and so, to use Newman's word, evokes faith. The content of the symbol that so stirs me has to do with the message of Jesus, with his life and mission, with his parables, his compassion, his devotion to the God he called Father, his concern for the marginalized. That he embodies all of this is what moves me - not that the fact that he is the only one who so embodies all this.

I know the analogy of marriage is imperfect and has been misunderstood, but I do think it is appropriate in this context. What inspired and moved me to commit myself and marry my wife (after a history of relationships in which I thought I would never be so moved!) was the conviction that what my experience and imagination told me about her was indeed true: that she was the good, the caring, the challenging person I felt her to be. It was not because I know she was the only such

13. Just how and why this subsequent mediation of the claim that Jesus is the ontologically sole source of salvation took place is a complex and ambiguous issue. I have offered some suggestions why the early communities of the New Testament made their "one and only" claims about Jesus, in No Other Name? A Critical Survey of Christian Attitudes toward the World Religions (Maryknoll, NY: Orbis Books, 1985) 182-186. 
good, caring, challenging woman in the world. I very well knew that there were other such wonderful women whom other men were marrying. Yes, in my cold, rational moments, I even knew that it would be theoretically possible for me to marry one of those other wonderful women. But I knew who this woman was; and I trusted what my imagination told me could be a life with her. And that was enough to fire and launch my trust and commitment. ${ }^{14}$ Something similar takes place in the process by which Christians come to realize that indeed Jesus is the Christ for them whom they choose to embrace in discipleship. "I know in whom I have believed" (Titus). They know, because they have so experienced, that Jesus is God's Sacrament of salvation. Whether there are other such sacraments is a question that does not, or need not, interfere with the "yes" they pronounce to Jesus their Savior. ${ }^{15}$

\section{Not the Final and Full Story}

I would suggest that if we look further into how the religious imagination works, we can discover that it does not inform us that the truth we have experienced in Jesus is the final and full truth that God has in store for humanity. In legal terms, while we can swear that we do feel that God's word in Jesus is "nothing but the truth," we cannot say that we feel it to be "the whole truth." So if in our previous reflections I suggested that the Christian religious imagination does not rule out the possibility of there being other saving stories, now I am suggesting further that neither does the imagination inform us that Jesus is necessarily the last, the definitive, story for all the others.

14. Where my analogy of marriage "limps" ("omnis analogia claudicat" - every analogy limps in some way) is on the issue of universality. While my relationship with Jesus is something that I feel is universally relevant and that I would want others to share in, the same is not true of my relationship with my wife. While the relationship between spouses has an intimacy that cannot be shared (expressed in part in their sexual relationship), the intimacy that I have with the Christ-living-in-me can be shared.

15. Another question might be posed to this marriage analogy: If Christians know that there might be "other saviors" besides Jesus, would this not jeopardize their commitment to him? Would they not be unsettled by the possibility that if they would ever meet such an other savior, they would have to change their commitment to Jesus? I think not. Again, the analogy with marriage helps: The depth and quality of my relationship with my wife - based on what I know to be true of her - is such that though there is the possibility of my meeting and marrying another woman, this possibility is, for my imagination, not real. I am happy and fulfilled - "saved" - in the relationship I have. Indeed, the depth and peace that I find in this relationship opens and frees me to meet other women, enjoy their friendship, learn from them - and so deepen my relationship with my wife. Analogously, the depth of my commitment to Jesus the Christ, frees me, even encourages, me to explore and learn from what God may have revealed in other religions and their saviors. 
Here we have to distinguish between decisive on the one hand, and final or definitive on the other. I stated earlier that the Christian imagination does present Jesus as decisive - in the sense that his message and the Spirit working through it calls me to decision, to cut off previous paths and follow that of Jesus and his community. The Jesus path becomes for me a new path, or a clearer path, or a now-possible path. That's different from it being the final or the definitive path. In following Jesus, I know where I stand, yes. But I also know that in following after him, I may be standing somewhere else tomorrow. The truth and the vision in his message and being that excite my imagination is, as they say, open-ended. There's more to come.

My experience of Jesus contains this sense of more to come not only because, as one might argue, openness is inherent in the very nature of truth. More so, this openness is contained in an ingredient of Jesus' message itself - an ingredient that New Testament scholars tell us was essential to Jesus' experience and proclamation: his eschatological vision. In him, the Reign of God was already present, but at the very same time, it was not yet present. ${ }^{16}$ Expressed more philosophically, futurity is part of the warp and woof of the Gospel. And if the very message of the Gospel tells us that we must expect more, that clearly means that the present content of the Gospel cannot say it all. It cannot be "final" or "definitive." Here we feel the paradox contained in what our imagination senses when it leads us to faith in Jesus: as certain as we are that he is God's Word for us, just as uncertain are we about what that Word really contains and what it will lead us to. To continue the paradox, the truth of Jesus that stirs us is, therefore, as firm in its commitment to Jesus as it is radical in its openness to the future that we meet when we meet others.

This lack - I can say this happy - lack of finality in the way the religious imagination presents Jesus to the Christian believer is also an outflow of another quality of the imagination's picture of Jesus that we have already looked at: the Truth and Power that we experience in him are as mysterious as they are real. Again, here I am making not a doctrinal but an experiential claim: in the way the Spirit in Jesus-the-Sacrament overwhelms our imagination, we feel that what we are encountering in him is as powerful as it is ineffable. Or, more philosophically: the Mystery we feel in Jesus is as transcendent as it is immanent, just as much beyond

16. Norman Perrin, The Kingdom of God in the Teaching of Jesus (Philadelphia, PA: Westminster Press, 1963) 158-206; Marcus J. Borg, Jesus in Contemporary Scholarship (Valley Forge, PA: Trinity Press International, 1994) 47-96; John Fuellenbach, The Kingdom of God: The Message of Jesus Today (Maryknoll, NY: Orbis Books, 1995) 79-100. 
us as it is given to us. That's part of the experience of Mystery. We wouldn't use the word "mystery" if we had a final or a full grasp of it. To experience Mystery in Jesus, as we feel and say we do, is to implicitly but truly say that Jesus hasn't said it all, that there's more to Mystery than what we have committed ourselves to in Jesus. This requires that we be open to other ways in which this Mystery may be at work in history and in others.

\section{A Pluralistic Theology Can Stir the Religious Imagination of Christians}

If this somewhat lengthy and personal exploration of how the Christian religious imagination works has any validity, then I believe we have laid the groundwork for answering the question posed to this conference: "Does a pluralist theology of religions spell the death of the religious imagination?" No it does not. Indeed, a pluralist, or mutualist, theology of religions is very much capable of stirring and nourishing the way the imagination creates and evokes faith in Jesus the Christ. As I have tried to lay out in greater detail elsewhere, a pluralistic Christology, as it is being developed by theologians such as Aloysius Pieris, Raimon Panikkar, Roger Haight, Michael Amaladoss and yes I would also add, John Hick - does affirm and clarify those attributes of Jesus that are necessary for his story to stir our imagination: ${ }^{17}$ Though pluralists theologians do question whether Jesus is the only saving act of God in human history, they clearly and strongly affirm that he is truly God's saving act for all human history. Their uncertainly about the unicity of Jesus as Savior and Son of God does not prevent them from continuing to recognize and even proclaim to others the universal relevance, the decisiveness, and even the indispensability of what the Spirit has revealed and released in the Christ event. ${ }^{18}$ The image of Jesus that a pluralist theology of religions presents to the assembly of Christians can, I believe, move the imagination of Christians to believe in Jesus as Son of God, to follow him

17. Aloysius Pieris, "Christ beyond Dogma: Doing Christology in the Context of the Religions and the Poor," Louvain Studies 25 (2000) 187-231. For a summary of Panikkar's Christology, see Knitter, No Other Name?, 154-157. John Hick, The Metaphor of God Incarnate (London: SCM Press, 1993). For Amaladoss and Haight, see note 2. Also: Paul Knitter, Jesus and the Other Names: Christian Mission and Global Responsibility (Maryknoll, NY: Orbis Books, 1996) 104-198.

18. Knitter, Jesus and the Other Names, 76-80. Leonard Swidler \& Paul Mojzes (eds.), The Uniqueness of Christ: A Conversation with Paul F. Knitter (Maryknoll, NY: Orbis Books, 1997) 7-11. 
as Savior in the practice of Christian life, and to sing his praises and their own gratitude for him in Christian liturgy.

It can do all this mainly because a pluralist Christology continues to hold up Jesus as God's sacrament or symbol of salvation. As I tried to lay out earlier, in unpacking the way the religious imagination works, we must talk about symbols. And for pluralist Christians, Jesus continues to be understood as, and to function in their lives as, God's Ursacrament - the primary sacrament whose energy is preserved and passed on in all the other sacraments of the Christian community. ${ }^{19}$

To translate this into the language of contemporary theological discussions, a pluralist theology of religions wants to ground itself on what is called a representative Christology, rather than a constitutive Christology. And it wants to do this not only in order to be more open to other religions but just as much in order to continue to nourish the Christian community in their proclaiming and following of Jesus. In order to grasp and weigh the differences between these two Christological perspectives, let me, once again, resort to distinctions I had to hone during my years of study at the Gregorian University back in the 60s: a constitutive Christology understands the saving role of Jesus principally as a causa efficiens, while a representative model sees that role as a causa exemplaris (I would prefer to call it a causa sacramentalis). As an efficient cause, Jesus saves us because he effected something, or did something - often understand as an act that in some way "repaired" the rift between God and humanity. As an exemplary or sacramental cause, Jesus saves because he shows or reveals something - he re-presents (that is, presents back to us) something that is already there but is not operative because we either cannot see it or trust it; this something is the saving love, presence, acceptance of the Divine.

Reasons why pluralist theologians prefer an exemplary causality are evident: An efficient cause is intrinsically singular. Once something is fixed, it can't be, or it doesn't need to be, fixed again. But an exemplary cause is at least potentially plural. What is revealed at one point in history might be revealed again in another. What is made know in one culture can be - we might even say, needs to be - made know differently in another. Or even more profoundly, when the content of what is being revealed is the illimitable and ever-dynamic Mystery of Divine Love and

19. According to Schubert Ogden, therefore, Jesus is both the representative and the constitutive cause of faith and salvation for Christians. See Is There Only One True Religion or Are There Many? (Dallas, TX: Southern Methodist University Press, 1992) 96-98. 
Presence, a multiplicity of exemplary causes or revelations is not only intelligible but even necessary. ${ }^{20}$

On this issue we are igniting, I suspect, some of the concerns about a pluralist theology that have called us together in this conference. To present and describe Jesus to the Christian imagination as an exemplary or representative cause of God's saving presence is, some object, to hold him up as only an example, a model, an illustration of who God is and what God wants to do. Such a Christology, it is argued, is barren of real ontological content. In it, Jesus is a wonderful figure, an "archetypal person" among other archetypal persons. But he is not integral to what God is up to in history. He doesn't make the difference or work the changes that Christian tradition has always claimed that he did. As Jacques Dupuis puts it: "... the Christian faith cannot stand without claiming for Jesus Christ a constitutive uniqueness: in him historical particularity coincides with universal significance." Only a constitutive Christology, according to Dupuis, preserves the traditional claim of Christianity that Jesus "constitutes the privileged channel through which God has chosen to share the divine life with human beings." 21

Terrence Merrigan spells out in greater detail and clarity what critics feel are the sore spots in the proposed representative Christology. To catch the detail and clarity, I quote at length from Merrigan's essay comparing two Englishmen, John Henry Newman and John Hick:

[According to John Hick and pluralist Christology] Jesus' relationship to God's saving power is contingent rather than ontological, or representational rather than constitutive. Jesus does not belong to the definition of God. Instead, he belongs to the history of God's encounter with particular men and women; he is an instance of God's saving presence, not its source or its cause.

Within the framework of traditional Christian faith, this centrality [of Jesus] is justified by the appeal to Jesus' substantial unity with the Godhead, that is to say, his status as the unique Son of God. The Jesus whom Christians approach in prayer, who animates their ethical praxis, and who encounters them as the protagonist of the Christian story is not a penultimate figure, a stepping stone on their journey toward the truly Real but the Real in person, God incarnate. Within the framework of tra-

20. As has been pointed out, even if we are working with a representative Christology, it is still well possible that Jesus is held up as the normative revelation in a world of many revelations. That certainly is true. But it need not be true. And that spells the difference between a representative and a constitutive Christology: as a constitutive cause, Jesus must be singular and normative; as a representative cause he can be one among others.

21. Jacques Dupuis, Toward a Christian Theology of Religious Pluralism (Maryknoll, NY: Orbis Books, 1997) 304, 305. Emphasis mine. 
ditional Christianity, we might say, Jesus, the mediator, provides immediate access to God Self. This notion of 'mediated immediacy' is at the heart of incarnational Christology. And ... it is at the heart of the divide between Newman and Hick regarding the role of the religious imagination. ${ }^{22}$

To carry on a conversation with these critics and their misgivings, I suggest that many of their concerns would be mitigated if not removed if we pluralist theologians would make clearer than we have in the past that when we speak about a representative Christology we mean a sacramental Christology. And, at least to speak for myself and my fellow Catholic pluralists, we mean "sacrament" in the full and traditional Catholic sense of that word. (Perhaps we should simply substitute "representative" with "sacramental.") With regard to Dupuis's objections, if we understand and experience Jesus as a sacramental, rather than a constitutive, cause of salvation, historical particularity does coincide with universality. What is symbolized or sacramentalized in the particular Jesus cannot be limited only to the Christian community. Yes, Jesus might not be the "privileged" channel any more, but as I have suggested, talk of "privilege" is just that - talk or language that has understandably been used in the course of Christian history; it does not arise within, nor is it required by, what the religious imagination feels to be salvific in Jesus.

As for Merrigan's objections to a representative Christology, I think they can be met, again, if we pluralists would make it clearer that we are speaking about Jesus not just as a "model" or an "example" but as a sacrament and symbol of divine love and saving power. By grasping just how a "symbol participates in what it symbolizes" and how a sacrament truly causes by symbolizing (symbolizando causant), Merrigan and others might find their concerns assuaged. As a sacrament or symbol of God, Jesus is not just a "contingent" vehicle of God's grace but participates ontologically in who God is, and yes, therefore is part of "the definition of God." As a sacrament, Jesus is not just "an instance of God's saving power," but also its "cause" - that through which this power is made real for humans.

Furthermore, as Roger Haight has shown, on the basis of a sacramental or symbolic Christology, one can coherently and persuasively affirm the "substantial unity of Jesus with the Godhead." When Merrigan rightly announces that "this notion of 'mediated immediacy' is at the heart of incarnational Christology," I remind him that I can say the same thing about a representative or sacramental Christology.

22. Terrence Merrigan, "The Image of the Word: Faith and Imagination in John Henry Newman and John Hick," Newman and the Word, ed. Terrence Merrigan \& Ian Ker, Louvain Theological and Pastoral Monographs, 27 (Leuven/Grand Rapids, MI: Peeters/W. B. Eerdmans, 2000) 33-34. Emphasis mine. 
But if we hold to Jesus as symbol and sacrament, we must also preserve the inherent dialectic, or "both-and," quality within the experience of a symbol. Insofar as Jesus is the mediated immediacy of God for us, he is, one must recognize, penultimate, for the symbol cannot be simply identified with the symbolized. But because Jesus is also experienced by the imagination to be the mediated immediacy of God in our lives, then we can authentically confess that he is "the Real in person, God incarnate."

This means that the divide between Hick and Newman, or between "representative and constitutive" Christologies, may not be as great as Merrigan fears. In traditional Catholic sacramental theology, to represent, or to symbolize, is to cause, or to constitute. Because symbols, in the very process of symbolizing, really do cause, a representative Christology is a constitutive Christology. But it is also a Christology that is open to other representations, other symbols and sacraments of the divine in other histories and religions. And that, for pluralists, is not only a big, but an essential and urgent difference.

\section{A Pluralist Christology Is a Dialogical Christology}

In fact, pluralist theologians are trying to show that a sacramental Christology implies that Christians are not only open to but actually in need of the sacraments and symbols of God that may be found in other religions. This is why I prefer to call myself a mutualist rather than a pluralist theologian of religions. Dubbed a pluralist, I am placed in the club of postmodernists whose primary intent is to affirm and safeguard diversity for the pure sake of diversity, out of the supposition that it is better to have "many" rather than "just one." But as a mutualist, as stated in the beginning of this paper, my driving concern is not simply to affirm the many but to bring them together in conversation and cooperation. A pluralist wants to allow "a thousand flowers to bloom." A mutualist wants to search for ways in which they might form a bouquet, each flower distinctive and beautiful, but all of them together even more distinctive and beautiful.

There are various ways in which theologians are elaborating why a representative or sacramental Christology is, by its very nature, a Christology of Mutuality - that is, an understanding and following of Jesus that requires an encounter with others, that is in need of relationship and conversation with those who are walking on other religious paths. Perhaps the most fundamental reason is this: if a Sacramental Christology 
recognizes not only the possibility but the probability, even necessity, of other symbols or sacraments of the Divine throughout history, it will also feel the necessity of learning about and from those other sacraments. And this will not simply be out of curiosity about what God is up to in other times and cultures. Rather, if the religious imagination has realized that what it has felt in Jesus is and must be universal, then it will expect that other religious persons, whose imaginations have been touched by other symbols, will be making similar universal claims. If Christians are driven, as it were, to let others know and feel and be transformed by what they have been given in Jesus the Christ, they must be, and will want to be, open to learning from, perhaps being transformed by, what their brothers and sisters in other religious traditions feel driven to share. Symbols call unto other symbols. In feeling my own, I am open to feeling yours. This is because, as we have said, in revealing to us that which is really true, a symbol never delivers the whole truth. To step closer to the whole truth, I need to explore your symbol.

Stated in more explicitly Christian terms, if Jesus is understand as the Word of God within a sacramental or representative Christology, then he is God's Word that can really be understood only if put into conversation with other of God's Words. No word can be really understood by itself. Words, either by their very nature or by the nature of the human mind, must be understood in sentences, in relation with other words. Even the most beautiful or powerful of the words in our vocabulary are inadequate if they stand by themselves. This is a consideration that even more cautious or conservative Christians might understand and accept: even if they feel compelled to hold up Jesus as God's final and full Word, they can also admit that they will never move closer to grasping and living what that "finality" or "fullness" mean if they are not relating God's Word in Jesus with God's Words among others. Such an admission would also satisfy a pluralist or mutualist Christian: whatever the finality of Jesus might mean, it's a finality that cannot stand alone, that cannot function without conversation with others; it's a dialogical finality. ${ }^{23}$

Another way in which theologians are attempting to show that Jesus is God's Word open to other Words - or, that an authentic Christology is necessarily a Christology of Mutuality - is through the symbol of kenosis. This perspective has been laid out extensively and powerfully in a soon-to-be published study by David H. Jensen. Unpacking the Pauline realization that Jesus' divinity and his role as savior is tied, tightly but mysteriously, to the act of emptying and letting go of himself in his love 
for and reaching out to others, Jensen arrives at a image of Jesus and discipleship that is essentially dialogical. In Jensen's own words:

Jesus Christ is the One who embodies openness to others ... He is the One who goes ahead of all who would enclose him, manifesting himself throughout time whenever openness to others is embodied in love.

[Therefore:] 'Christomonism' - the proclamation of Jesus Christ at the expense of everything else - is a distortion of the life of discipleship and not its faithful execution. Indeed, conformity to Christ involves being claimed by others, and not claiming others as our own ... In order to become more faithful disciples, Christians need the insights of persons who profess distinctly different religious commitments. ${ }^{24}$

A clarification is needed here: when we say that a kenotic Christology, or a sacramental Christology, is by its very nature a Christology of mutuality, we really mean mutuality in the comprehensive, dialectical sense of that word. An openness to others and a conversation with them that is truly mutual means that the relationship can be mutually (that is, for both sides) both fulfilling and disrupting. From my Christian side of the dialogue, that means that Christians will not only find themselves agreeing with others in so far as they discover new treasures in what God has been up to in other religions; they can also find themselves having to confront, even flat-out disagree, with others. This will happen whenever they encounter beliefs or practices that are contrary to the vision of God and the Kingdom that Jesus embodies and reveals. Certainly, as Roger Haight reminds us, what in the dialogue at first sight looks like a contradiction may often be an invitation to approach our own truth in an utterly different way; we must be careful not to confuse contradictions with paradoxes. Still, contradictions in an interreligious conversation, especially in ethical issues, can and do occur. ${ }^{25}$ In such cases, humble, compassionate, but at the same time clear and firm disagreement, even confrontation, may be part of the dialogue. "Mutuality" can be both delightful and distressing, both mystically uplifting and prophetically messy.

24. David H. Jensen, In the Company of Others: A Dialogical Christology (Cleveland, OH: Pilgrim Press, 2001) xi-xv, passim.

25. Haight, Jesus Symbol of God, 407-408. In this context, Haight reminds us that in such openness to and dialogue with others, Jesus continues to be normative for Christians. But it is what he calls a negative, rather than a positive, normativity: what we encounter in other religious traditions can be something genuinely new and therefore add to what God is revealing to us; but it cannot really contradict what we have found to be true in Jesus. See Jesus Symbol of God, 409-410. 


\section{A Pluralist Christology Is Stirring the Religious Imagination of Christians}

To return a final time to our opening question: does such a theology or Christology of mutuality (what our conference is calling a pluralist theology of religions) "spell the death of the religious imagination?" I conclude not only with a resounding "no!" I can also claim that it is adding to the life of the religious imagination in Christian communities throughout the world. Here I enter the area of pastoral theology; my assertions are what might be called "impressionistic." But I trust that my impressions are clear enough and common enough to be trustworthy. Both in my own experience in the university classroom or in parish discussion groups, as well as in what I read about and have sometimes seen in both European and Asian churches, there is a growing number of Christians who are at least uneasy about, if not downright scandalized by, what they are told they have to believe about other religions. I think this uneasiness or scandal erupted in the widespread negative, sometimes even angry, response to the Congregation of the Faith's recent document Dominus Jesus. From various quarters of the Catholic community there came a resolute response: "This is not our faith." One might call this reaction an example of the "sense of the faithful" in tension with the sense of the official magisterium.

The tension, or scandal, revolves around the one word: only. Christians are finding it increasingly difficult- both in their own hearts and before their friends in other religious communities - to maintain that only in their religion does one find the final and full Truth about God and humanity because only in Jesus Christ has God made possible and so constituted the salvation of all. Increasingly, this "only" is making it difficult for the religious imagination to find in the story and sacrament of Jesus the message or power that truly enlightens their lives and excites their faith. As Newman reminds us, even though the imagination can help us, as it were, to leap over certain intellectual gaps and jump from "probable" to "certain" (or from "notional" to "real" assent), still the imagination, Newman admits, can only "intensify," not "create" the truth of what we believe. For Newman, the truth or validity of faith remains grounded in reason and the intellect. Therefore, he tell us: "in religion, the imagination and affections should always be under the control of reason." ${ }^{26}$ And if reason, when it confronts traditional Christian claims

26. John Henry Newman, An Essay in Aid of a Grammar of Assent (London: Longmans, Green \& Co., 1870), 81, 98-99. See also Terrence Merrigan, Clear Heads and Holy Hearts: The Religious and Theological Ideal of John Henry Newman, Louvain Theological and Pastoral Monographs, 7 (Louvain: Peeters Press, 1991) 187-189. 
about salvation only through Jesus, is presenting Christians with personal, pastoral problems, those problems must be taken seriously. This is why I have so often heard expressions of gratitude from Christians when I report to them how theologians are trying to grapple with the problem of this "only." They confess that this is a question that has long unsettled and pained them but one that they thought was simply "off-limits" for Christian consideration.

The reason why this pastoral problem is growing so acute today has to do, I suggest, with a widespread conflict or contradiction, especially in the Roman Catholic Church, between the theory and practice of dialogue with other religions. Vatican II, mainly in Nostra Aetate, opened the doors of dialogue for Catholics and not only allowed but "exhorted" them to pass through and "prudently and lovingly, through dialogue and collaboration with the followers of other religions, and in witness of Christian faith and life, to acknowledge, preserve, and promote the spiritual and moral goods found among these people..."27 Well, Catholics are doing just that. In parish discussion groups with Muslims, in collaborative projects with Hindus and Jews, in meditation courses using Zen or Hindu methods, through reading and study in classrooms and study groups, Catholics have come to realize that there are more "spiritual and moral goods" in other religions then they ever realized. Even more so, they have seen with their eyes and felt with their hearts the depth of spirituality in Hindus or Muslims who have become their friends, their neighbors, maybe even their sons or daughters in law. And from all these forms of dialogue - described by the Vatican as dialogues of spirituality, of study, or of life - Catholics have found themselves not only impressed but enriched. ${ }^{28}$ They have realized, as Edward Schillebeeckx puts it, that there is more of God's truth and presence in all the world religions together than there can be in any one of them, including Christianity! ${ }^{29}$

The fruits of such a practice of dialogue stand in tension with a theology of religions that insists that the fullness of revelation resides in Christianity or that other believers, to find their true happiness, must be fulfilled in Christ and his Church. Such theological claims seems to contradict what the practice of dialogue reveals. And this means that the Church has a problem - a problem that it must take more seriously and creatively than it has in the past. Such a situation is nothing new in the history of the Church. It reflects the same dynamic contained in the traditional recognition that there can be a dissonance between the practice

27. Nostra Aetate, \#2.

28. See the statement of the Vatican Council for Interreligious Dialogue, Dialogue and Proclamation (1991), nos. 42-43.

29. Schillebeeckx, Church: the Human Story of God, p. 166. 
of the lex orandi (or the rule of prayer/liturgy) and the theory of the lex credendi (the rule of creed/theology). In our case we might speak of a clash between the lex dialogandi and the lex credendi - the practice of interreligious dialogue and the theology of religions. Whenever the Church finds herself in such situations of dissonance or clash between theory and practice, or between pastoral experience and creedal or theological formulation, we have not just a problem, but an opportunity. In wrestling with the tension there is the need and the new possibility of both clarifying our practice of dialogue and expanding our theology of religions. ${ }^{30}$

Should this expansion follow the lines of a pluralistic or mutualistic theology of religions, such as I have been suggesting? That we cannot say. Such a question can be answered only through the process of theological reflection tested in pastoral application. Such a question can only be answered, in other words, within the life of the Church - the interplay and intercommunications of pastoral leaders, theologians, and especially the sense of the faithful. It seems, however, that it is precisely this kind of exploration and evaluation within the life of the Church that some of our pastors in Rome are trying to prevent, in declarations such as Dominus Jesus, and restrictions placed on theologians who are doing this kind of explorations, such as Jacques Dupuis, Roger Haight, and Tissa Balasuriya.

But the tension between the practice of dialogue and the theology of religions will not go away. This was and continues to be seen especially in the life of the Asian Churches, as that life was expressed before, during, and after the 1999 Synod of Asian Bishops. The bishops stated clearly, before the Synod and afterwards, that traditional - or Western formulations of the uniqueness of Christ and the place of Christianity among religions are simply not working, not appropriate, for their efforts to preach and live the Gospel in Asia. ${ }^{31}$ What is so sharply and painfully focused in the Asian churches is present, perhaps in milder forms,

30. I have tried to describe and analyze this clash between the practice of dialogue and the theology of religions in "Catholics and Other Religions: Bridging the Gap between Dialogue and Theology," Louvain Studies 24 (1999) 319-354.

31. For references, see Knitter, "Catholics and Other Religions," 333-335. As Edmund Chia states in his paper to the Seventh Plenary Assembly of the Federation of Asian Bishops, Jan. 3-12, 2000: “... when the Curia bishops insist that the bishops of Asia address the issue of Jesus as the 'one and only saviour', it is like a Vietnamese bishop insisting that the Church in Italy address the issues of ancestor worship amongst Italian Catholics, or like an Indian bishop asking that the Italian bishops address the problem of the caste system or the dalit problem in their Italian parishes" (Manuscript titled "Interreligious Dialogue in Pursuit of Fullness of Life in Asia"). 
throughout the Church: traditional theological understandings of the uniqueness of Jesus and the role of Christianity are not working well to ground, interpret and direct Christians' experience of and dialogue with followers of other religions. Perhaps when the bishops of Vatican II recognized the "spiritual and moral goods" within other religions and then sounded their call to all Catholics to dialogue with these religions, this was another instance in which, as Karl Rahner has observed, they didn't fully realize the implications of what they were doing. In opening, as it were, the floodgates of dialogue, they also opened a flood of new theological questions about Jesus and the Church that require genuinely new answers. ${ }^{32}$ These questions, it seems, have not yet be sufficiently answered in order to sustain the life of the Church and to nourish the Christian religious imagination. Theologians and pastors and bishops, still have a lot of work to do.

And as I have tried to show in this paper, it has been my experience - both personally and as a teacher/minister - that a pluralistic or mutualistic theology of religions is inspiring the imagination and nourishing the faith of Christians who are as fully committed to Christ as they are open to and engaged with other religions. I saw this clearly and powerfully two summers ago in a workshop in Thailand with some 90 religious educators, ministers, pastors from all over Asia. ${ }^{33}$ I experienced it again this past semester in a graduate course with mainly Catholic high school teachers and ministers. In both these groups, I encountered Christians for whom an image of Jesus as truly God's word and gift of salvation to all people, but not necessarily God's only saving gift to all, could both inspire their faith and commitment to Jesus and free it to grow and deepen. If there is anything to the old scholastic adage, ab esse ad posse valet illatio - from what is one can validly conclude to what is possible - then we have a pretty clear answer to our conference's question: "Can a pluralistic theology sustain Christian imagination and faith." It can do so because it is doing so.

32. William Burrows indicates just how new these answers might be: "That contemporary interreligious interchange will do to the doctrine of soteriology what interchange with sciences such as paleontology and astrocosmology did to the doctrine of creation." In a paper "A Catholic Perspective on What Evangelicals Have to Contribute to Interreligious Interchange," Nov. 1999.

33. The Second Formation Institute for Interreligious Affairs (FIRA II), July 8-13, 1999, Redemptoris Center, Pattaya, Thailand, organized by the Federation of Asian Bishops Conferences, Office of Ecumenical and Religious Affairs. Report to be published next year in the book, For All the Peoples of Asia. 